\title{
The Implementation of Student Team Achievement (STAD) Cooperative Learning Model in Traditional Vocal Subject of North Sumatra
}

\author{
Lamhot B. Sihombing \\ Music Education Study Program, Faculty of Language and Art, Universitas Negeri Medan, Indonesia. \\ Email: b4khrul.4m41@gmail.com
}

\begin{abstract}
This study aims to determine the application of the STAD model of cooperative learning in learning the songs of the North Sumatra region in semester 2 students in the music education program at Universitas Negeri Medan. The problems to be discussed are: How is the application of the STAD model of cooperative learning in analyzing the main melodies of North Sumatra regional songs and how are the learning outcomes using the STAD model of cooperative learning methods. This study uses two approaches namely quantitative and qualitative methods with data collection techniques in the form of literature studies, observations, interviews, tests in the form of pre-test and post-test as well as analyzing learning outcomes. After the classroom action research process, the results were obtained that: in the application of the STAD model of cooperative learning in the material analysis of the main melodic form of North Sumatra regional songs in the second semester students of music education study program, it showed positive results and showed an increase in students' abilities. This is done for several stages, namely through cycle I and cycle II. In the trial test, the pre-test grade averages 52.3. The average grade that has been obtained is very low. Then conducted an experiment with a cycle I (post- test I) then the average grade increased by 66.33 but was declared incomplete. Furthermore, it is done by cycle II (post-test II), then the total number of class grades is increasing, amounting to 79.5 so that the value is declared complete and the cycle is not resumed. So, it can be concluded that the application of the STAD model of cooperative learning in learning the songs of the North Sumatra region in semester 2 students in music education study program has increased learning outcomes. This shows that STAD type cooperative learning can be used as an alternative in improving student learning outcomes in vocal learning of North Sumatra regional songs.
\end{abstract}

Keywords: learning; cooperative; model; STAD

\section{Introduction}

In every curriculum surely has a goal so that learning outcomes can achieve goals with good results in each learning process. In reality this task is not easy, it takes a variety of strategies and methods to be able to achieve the learning objectives well. Various problems will be faced by a lecturer or instructor in the class, including the problem of how to plan and manage learning, so that it is achieved in accordance with the expected competencies. It must be recognized that the development of learning strategies is one way to provide and broaden students' insights about knowledge, skills and other basic values in the hope that they can be reflected in the habits of thinking, acting and behaving. However, the general student has a very strong dependence on how he is treated by a lecturer or educator. That is, the success of students mastering competencies with regard to specific teaching materials depends very much on how educators design effective learning.

Achieving the success of teaching objectives is a target in carrying out learning activities. For this reason, educators must always try to develop methods and techniques that are considered effective. When educators provide presentation of teaching material, it is always 
expected that students can master the learning material well. But in reality, this often does not happen. This situation is caused by the lack of reinforcement about the dimensions of the teaching material provided. This means that concepts, facts, and principles are accurate when they do not experience overall reinforcement, or in other words are only stored in short-term memory (short them memory). In addition, the teaching system is still focused on educators/ lecturers as the main source of knowledge (teacher oriented) supported by conventional methods as the main choice in learning. For example in the one of cases study of Purnama, et al (2020) There are 5 categories of achievement of fine motor development consisting of drawing according to patterns, imitating shapes, using stationery, cutting, and sticking. Based on the results of observational analysis and interviews, it appears that the achievement of fine motor students in the drawing stage is considered successful because the students is able to draw as desired.

Learning model is one of the factors that influence learning outcomes and the quality of education. In learning, a good learning model design must be done so that it can provide good learning outcomes. Errors in the choice of teaching methods and models can result in the failure to achieve teaching objectives. Patricio (2019) said that there was a statistically significant differences in the academic achievement between the average mark of the experimental group students and the average mark of the control group students in favor of the experimental group.

This issue will be seen in the process of learning to sing songs from the North Sumatra area in Universitas Negeri Medan of Music Education Study Program as the locus of this study. Based on observations and preliminary observations of this study that students are still less fully involved in the teaching and learning process, teachers still play a major role while students are not actively involved as a whole, many students are not motivated to learn traditional North Sumatra songs. This will result in a situation that is not conducive, and in the end greatly affect learning outcomes. In this case student learning outcomes specifically in understanding the material of traditional North Sumatra songs are less than optimal or less successful, students over $60 \%$ get incomplete grades. Based on the above situation, it should be designed an appropriate method in order to improve student learning outcomes. Learning outcomes are abilities obtained by children through learning activities. Therefore, it is necessary to conduct a trial to participate in activating students in the learning process, namely by implementing cooperative learning model STAD (Student Team Activism Division) which emphasizes the activeness of students in study groups. How this learning process will take place and how the results become the focus in the study design conducted.

\section{Literature Review}

Learning methods are procedures, sequences, steps, and methods used by teachers in achieving learning objectives. It can be said that the learning method is a description of the approach. One approach can be translated into various learning methods. It can also be said that the method is a learning procedure that is focused on achieving goals.

Knowledge about teaching methods is very much needed by educators, because the success or failure of students to learn depends very much on whether or not the teaching method used by the teacher. Learning is the process of interaction of students with educators and learning resources in a learning environment. Learning is an assistance given by educators so that the process of acquiring knowledge and knowledge, mastery of skills, and the formation of attitudes and beliefs in students. In other words, learning is a process to help students to learn well. 
In traditional opinion, learning is only considered as the addition and collection of a number of knowledge. This opinion is too narrow and simple and only focuses on subjects. Learning is not just about gathering knowledge, but learning is more emphasis on changes in individuals who learn. This is as said by Lester D. Crow and Alice Crow (in Kunandar: 2008), that learning is an individual change in habits, knowledge, and attitudes. According to this definition a person experiences a learning process if there is a change from the unknowing to the knowing.

1. Walker in Riyanto (2008) states that: "Learning is a change and implementation of tasks that occur as a result of experience and has nothing to do with spiritual maturity, fatigue, motivation, changes in stimulus situations or other factors that are not directly related to learning activities ".

2. Meanwhile, according to Winkel in Riyanto (2008) "Learning is a mental / psychological activity that takes place in active interaction with the environment, which results in changes in knowledge, understanding, skills, and attitude values".

3. Cronbach in Riyanto (2008) states that: "Learning is a change in behavior as a result of experience. According to Cronbach that the best learning is to experience something that is using the five senses.

According to Riyanto (2008), psychologically learning is a process of changing behavior as an interaction with the environment in meeting their needs with the characteristics of:

1. Changes occur consciously, for example he realizes that his knowledge has increased.

2. Changes in learning are functional, meaning that students benefit from the knowledge they receive and get.

3. Changes in active learning are positive means that the change is always increasing and aimed at getting something better than before.

4. Changes in learning are not temporary, but are permanent.

5. Changes in learning include all aspects and behavior.

Teachers as instructors are not only the origin of teaching and delivering subject matter to students, but more than that teachers are expected to have the right strategy so that students do not stop learning, but will continue to look for and deepen their knowledge.

In line with the above, according to Soelaiman in Erlindayani (2007) that: "Teaching is the activity of teachers guiding and helping students gain experience that is useful for the development of all the potential they have as much as possible". Teaching is a human activity in human relations. Therefore, teaching is truly human in nature.

According to Erlindayani (2007), the ability of teachers to manage teaching and learning in class is grouped into 3 (three) classes, namely:

1. Ability to plan teaching.

2. The ability to carry out teaching and learning.

3. The ability to evaluate / assess teaching results.

In preparing a teaching plan one of the important elements to be considered by the teacher is the selection of teaching methods. The teaching method is a unitary work step developed by the teacher based on certain rational considerations, each of which has a distinctive pattern and all are useful for achieving teaching objectives (Erlindayani: 2007).

Learning outcomes appear as changes in behavior in students that can be observed and measured in the form of changes in knowledge, attitudes, and skills. These changes can be 
interpreted as an increase and development that is better than before, for example from not knowing to knowing, impolite attitude to being polite, and so on. Student learning outcomes include three aspects, namely aspects of concept understanding, aspects of reasoning and communication, and aspects of problem solving (Umamik: 2007).

\section{a. Definition of Cooperative Learning}

According to Riyanto (2008), cooperative learning is a learning model designed to teach academic skills, as well as social skills, including interpersonal skills.

There are many ways in cooperative learning to be used in the classroom. The basic facts of learning are understanding concepts, high-level reasons, problem solving, and application that allow the best actions in cooperative learning groups.

Kempatal (1994: 151) in Syafaruddin (2005) states that: "Cooperative learning is a special type of group activity that seeks to advance learning and social skills by collaborating three concepts into teaching, namely: (a) group rewards, (b) personal accountability, and (c) equal opportunity to succeed."

Based on the three components, it is suggested that cooperative learning requires careful planning and systematic implementation. Cooperative learning is more directed at tutors and other student group members or perfecting activities.

\section{b. The characteristics of cooperative learning}

Riyanto (2008), states the characteristics of cooperative learning, namely:

1. Groups are divided by high, medium, low ability students.

2. Students in groups live semati.

3. Students see all members have the same goals.

4. Sharing duties and responsibilities equally will be evaluated for all.

5. Share leadership and skills to work together.

6. Asked to be responsible for the individual material handled.

\section{c. STAD (Student Team Achievement Divisions) Cooperative learning method}

The STAD type was developed by Robert Slavin and his colleagues from John Hopkins University. This method is seen as the simplest and most direct approach to cooperative learning. This type is used to teach new academic information to students every week, both through verbal and written presentation. Team members use activity sheets or other learning tools to complete the subject matter and then help one another to understand the lesson material in a tutorial, quiz each other.

STAD is one of the simplest cooperative learning methods, and is the best model for beginners for teachers who are new to using a cooperative approach. Based on the opinion above, it can be concluded that the STAD type cooperative learning model is a learning model that is carried out by dividing students into small groups and using activity sheets or other learning tools to complete the subject matter. According to Sitepu (2019) is to improve students' language reasoning skills, especially students of Mathematics Education and Accounting Education in order to continuously implement cooperative learning models.

The parts of the STAD type of cooperative learning are: the students in the class are divided into groups, each consisting of 4 or 5 group members. Each group has heterogeneous members, both gender, race, ethnicity, and abilities. Each group member uses an acadamic 
worksheet, then helps each other to master the teaching material through question and answer or discussion among fellow group members. Individual or group evaluations are carried out by teachers to find out their mastery of academic material that has been studied. Each student and each group is given a score for their mastery of teaching materials, and individual students or groups who achieve high achievements or obtain perfect scores are given awards.

\section{Research Methods}

The research method is generally interpreted as a scientific way to obtain data with specific goals and uses, where the scientific way here means that a research activity is based on scientific characteristics that are rational, empirical, and systematic. In this research, the method used is a classroom action research method. Classroom Action Research is also called Classroom Action Research. Classroom action research (CAR) is a form that is reflective by taking certain actions in order to improve and enhance classroom learning practices in a professional manner. Some forms of classroom action research as a form of classroom action research steps, namely:

1. Teachers as researchers

2. Collaborative action research.

3. Simultaneous integration.

4. Experimental social administration

The form of classroom action research used here is the first form, namely CAR that views teachers as researchers. In this form the main goal of CAR is to improve teaching practices in the classroom where the teacher is directly involved in planning, action, and reflection.

Some CAR models that can be developed include:

1. Kurt Lewin's Model.

2. Kemmis and Mc. Taggart.

3. John Elliot's Model.

4. Hopkins model

PTK research model used is the Kemmis and Mc. Taggart which is the development of the basic concepts introduced by Kurt Lewin. Kemmis and Mc. Design Taggart uses a model known as a spiral reflection system which consists of four components, namely planning, action, observation, and reflection.

\section{Discussion}

The research began in August 2019, by conducting observations, interviews by holding an initial dialogue between researchers, heads of study programs, teaching teams and students. The meeting expressed the intentions and objectives of the researchers to be carried out. The dialogue is also used to find out the initial state of learning, before action is taken. From this initial dialogue, data was obtained that the average student learning outcomes were very low. This is due to lack of student motivation, students are less active in following the lessons and student understanding of the material is still not good.

In observations made before implementing actions using the STAD (Student Team Achievement Divisions) cooperative learning method, it can be seen that the methods and learning models used have not been able to improve learning outcomes. The methods and models applied in learning to sing traditional North Sumatra songs are among the most conventional methods. So that in the learning process is still less active, students still cannot receive detailed learning. Based on these conditions, the researcher intends to conduct research to 
improve learning outcomes using the cooperative learning method STAD (Student Team Achievement Divisions) model. Action solutions to the problems offered in this study. With the application of STAD type cooperative learning methods, it is expected to be able to change the previously passive learning to become more active.

At the initial meeting the researcher gave a test to the students to find out the extent to which the students' ability to understand the material analysis of the basic molodic form of North Sumatra traditional songs, by conducting a pre-test and a practical test, became a reference to determine the feasibility of students to be able to solve problems together while learning took place later. At this initial meeting, it was found that students' data were not able to understand some of the tests that researchers gave to students.

From the results of the singing practice pre-test, it was concluded that $10^{\text {th }}$-A class students were still less able to analyze the main melodic form of traditional North Sumatra songs.

Table 1. Student Ability Data Based on Pre Test Results

\begin{tabular}{|l|l|c|c|}
\hline No & \multicolumn{1}{|c|}{ Name } & Grade & Note \\
\hline 1. & Pransiska Pasaribu & 30 & Not complete \\
\hline 2. & Andika kurniawan & 80 & complete \\
\hline 3. & Angga Ramadhan & 40 & Not complete \\
\hline 4. & Annisa Kartika & 60 & Not complete \\
\hline 5. & Baruna Fajar & 40 & Not complete \\
\hline 6. & Christian Natanael S & 30 & Complete \\
\hline 7. & Citra Olivia Damanik & 40 & Not complete \\
\hline 8. & Dinda Syafira & 40 & Not complete \\
\hline 9. & Deni Anju Purba & 80 & Complete \\
\hline 10. & Egy Andreas P & 40 & Not complete \\
\hline 11. & Ester Yuniarti Naiangolan & 80 & Complete \\
\hline 12. & Fadli Septiawan & 40 & Not complete \\
\hline 13. & Fauzi Mahyar & 30 & Not complete \\
\hline 14. & Indah Prima S. & 40 & Not complete \\
\hline 15. & Inka Fradilla & 50 & Not complete \\
\hline 16. & Jerri Mandela simamora & 50 & Not complete \\
\hline 17. & Klarisa Indah Pasaribu & 30 & Not complete \\
\hline 18. & Malik Adwi & 90 & Complete \\
\hline 19. & Nesya Kharisma & 40 & Not Complete \\
\hline 20. & Novita Sari nasution & 90 & Complete \\
\hline 21. & Ningot Rumapea & 50 & Not complete \\
\hline 22. & Natanael S & 20 & Not complete \\
\hline 23. & Randa Khrisna & 50 & Not complete \\
\hline 24. & Irvan Oscar & 30 & Complete \\
\hline 25. & Riska Gusti & Complete \\
\hline 26. & Septi Nanda & Somplete \\
\hline 27. & Sephia Ester & Swatutri Pratama & Not complete \\
\hline 28. & Marito bastian P & & \\
\hline 29. & & & Notete \\
\hline
\end{tabular}


Vol. 2, No. 1, March 2020, Page: 455-466

\begin{tabular}{|l|c|c|c|}
\hline 30. & Tri Mario Yolanda B & 50 & Not complete \\
\hline & Total & 1570 & \\
\hline & Average & 52,3 & Not complete \\
\hline
\end{tabular}

From the table above shows that of the 30 students, only 8 people have finished studying and 22 students are still classified as incomplete. Based on the pre-test in general, it is still classified as incomplete. Thus, it can be stated that the initial ability of students in learning to analyze the basic melodies of North Sumatra regional songs is still very low.

\section{a. Cycle I}

\section{- Planning for Cycle I Actions}

This research directly involves 3 parties, namely researchers, Vocal Lecturer Team, and 2nd semester students who take traditional vocal courses. The lecturer team acts as a teacher in the learning process in the classroom, the researcher acts as an observer who records every incident that occurs during the learning process takes place, while students as objects in research. The observations obtained by the observer will be discussed together as input in the implementation of learning which will then be reflected back. Furthermore, the results of this reflection will be concluded and action taken to improve the implementation of the next step. Then the steps are carried out together, a revision is made for the implementation of actions in the next cycle if the first cycle needs improvement in order to achieve maximum results determined by researchers.

The steps or plans to be carried out by researchers are as follows:

1. The researcher develops the material by preparing a Learning Implementation Plan (RPP).

2. Researchers compile observation sheets of learning activities.

3. The researcher develops an action evaluation tool.

4. Carry out the learning process with STAD type cooperative learning methods in learning the basic theory of music.

5. Monitor every student activity in the learning process, both when applying the STAD type cooperative learning method takes place.

\section{- Implementation of Actions I}

In the implementation phase of the first cycle of action carried out in two meetings, once a learning process meeting and once a meeting for the post test. Researchers carry out learning activities that last for 90 minutes and are observed by an observer by providing an observation sheet for observations of learning that will take place. The researcher plays a role as part of the lecturer team and participates in carrying out the learning process in the classroom.

Before entering into the learning process the researchers together with several students designed the class, which is to make it in several groups according to the STAD type cooperative learning method. When the learning process will begin the students immediately sit according to the group determined by the researcher together with the lecturer team. After students sit in their respective groups, the lecturer team conducts an opening activity. The goal is to condition students to follow the lessons well.

In the core activity, the researcher conducted the STAD type cooperative learning process, by explaining the learning material in the form of observing the song's basic melodic form. Researchers give assignments to students, to be done in groups. Then the researcher is always actively monitoring student activities, especially to groups that experience obstacles. After they finish answering the questions the researcher gave, the researcher gives the opportunity to 
groups who have finished going forward to the class to show the results of their work to the class. Next, the researcher gave an assessment of each group and the learning closed with a closing greeting. In this first meeting there were some students who were not yet able to analyze the melody of the song melody as in the initial test (pre-test).

At the second meeting, held in 90 minutes. The lecturer team repeated the previous material, namely learning to analyze the shape of the song melody. At the specified time the researchers conducted a post-test I to determine the ability of students. Researchers tested one by one student to move forward. During the test the researcher evaluates the students.

Table 2. Learning Cycle I Test Results (Post Test I)

\begin{tabular}{|c|c|c|c|}
\hline No & Name & Grade & Note \\
\hline 1. & Pransiska Pasaribu & 60 & Not complete \\
\hline 2. & Andika kurniawan & 80 & Complete \\
\hline 3. & Angga Ramadhan & 60 & Not complete \\
\hline 4. & Annisa Kartika & 60 & Not complete \\
\hline 5. & Baruna Fajar & 50 & Not complete \\
\hline 6. & Christian Natanael S & 90 & Complete \\
\hline 7. & Citra Olivia Damanik & 80 & Complete \\
\hline 8. & Dinda Syafira & 60 & Not complete \\
\hline 9. & Deni Anju Purba & 40 & Not complete \\
\hline 10. & Egy Andreas P & 80 & Complete \\
\hline 11. & Ester Yuniarti Naiangolan & 50 & Not complete \\
\hline 12. & Fadli Septiawan & 80 & Complete \\
\hline 13. & Fauzi Mahyar & 50 & Not complete \\
\hline 14. & Indah Prima S. & 60 & Not complete \\
\hline 15. & Inka Fradilla & 60 & Not complete \\
\hline 16. & Jerri Mandela simamora & 50 & Not complete \\
\hline 17. & Klarisa Indah Pasaribu & 80 & complete \\
\hline 18. & Malik Adwi & 40 & Not complete \\
\hline 19. & Nesya Kharisma & 90 & complete \\
\hline 20. & Novita Sari nasution & 80 & complete \\
\hline 21. & Ningot Rumapea & 90 & complete \\
\hline 22. & Natanael S & 50 & Not complete \\
\hline 23. & Randa Khrisna & 80 & Tuntas \\
\hline 24. & Irvan Oscar & 50 & Not complete \\
\hline 25. & Riska Gusti & 80 & complete \\
\hline 26. & Septi Nanda & 90 & complete \\
\hline 27. & Sephia Ester & 90 & complete \\
\hline 28. & Swatutri Pratama & 60 & Not complete \\
\hline 29. & Marito bastian P & 60 & Not complete \\
\hline 30. & Tri Mario Yolanda B & 50 & Not complete \\
\hline & Total & 1990 & \\
\hline & Average & 66,33 & Not complete \\
\hline
\end{tabular}

From the table above it can be seen that the students' abilities in learning are still relatively low. The average value obtained by students is 66.33 out of 30 students. From the level 
of mastery learning there are only 13 students, while students who are not complete there are 17 students. Then proceed to cycle II.

\section{- Observation of cycle I}

From the observations made during the first cycle which were carried out in two learning meetings it was not successful due to the non-optimal learning which was carried out in accordance with the STAD type cooperative learning method. In addition, some students have not been able to capture the learning that has been given. Besides students, the lecturer team is still not optimally carrying out their duties in the learning process. After the test results are checked, it seems that completeness has not been reached. For this reason, better actions are needed to further enhance the ability of students in learning to analyze the basic form of song melodies.

\section{- Reflection and Evaluation of the Implementation of Cycle I Actions}

In this reflection the researcher discusses with the vocal lecturer team to reflect the actions taken by the researcher. From the observations it can be seen that the learning process that has been implemented has not been optimal. This happened because the students did not yet understand the proper procedures for implementing STAD cooperative learning methods. So the class is less conducive. In this case, the learning steps that have been prepared by researchers in the CSP have also not been able to be implemented well.

\section{b. Cycle II}

Based on the results of reflection, evaluation and data analysis in the first cycle, the problem that needs to be fixed is during the learning process that is not optimal because most students do not understand well the procedures for implementing STAD type cooperative learning methods. And things that happen in the field, namely in class management is not optimal at the time of learning, so learning is still not one hundred percent conducive.

\section{- Planning Phase Cycle II}

The results of the post-test I were discussed together as input for the implementers of the second cycle, from the results it was concluded and corrective action was taken as the next implementation step.

The steps or plans to be prepared by researchers are:

a. Develop teaching materials and prepare Learning Implementation Plans (RPP).

b. Hold post-test II.

c. To overcome students who lack understanding of the concept, researchers will re-explain the material that was explained in cycle I.

d. To overcome students' mistakes in determining the final results, researchers planned to give direction to students to be more careful in the final results.

\section{- Stage of action II}

In the implementation phase of the second cycle of action, the researcher again explained the learning of the main song melodies analysis form, until students really understood about learning. Then at this meeting the researchers held a post-test II to see the extent to which the students' success in solving problems in analyzing the basic melodic form of the song. Before the post test is conducted, the researcher gives time for students to ask questions that do not understand, so that the post test can produce good grades. After that the researchers gave a post test to students using the STAD type cooperative learning method. During the test the researcher 
and the lecturer team monitor the students so they can evaluate things that are not yet understood. Then the test went smoothly, and got satisfying results.

Table 3. Hasil Tes Belajar Siklus II (Post Test II)

\begin{tabular}{|c|c|c|c|}
\hline No & Name & Grade & Note \\
\hline 1. & Pransiska Pasaribu & 90 & Complete \\
\hline 2. & Andika kurniawan & 80 & Complete \\
\hline 3. & Angga Ramadhan & 80 & Complete \\
\hline 4. & Annisa Kartika & 90 & Complete \\
\hline 5. & Baruna Fajar & 60 & Not Complete \\
\hline 6. & Christian Natanael S & 90 & Complete \\
\hline 7. & Citra Olivia Damanik & 80 & Complete \\
\hline 8. & Dinda Syafira & 80 & Complete \\
\hline 9. & Deni Anju Purba & 60 & Not Complete \\
\hline 10. & Egy Andreas P & 80 & Complete \\
\hline 11. & Ester Yuniarti Naiangolan & 70 & Complete \\
\hline 12. & Fadli Septiawan & 80 & Complete \\
\hline 13. & Fauzi Mahyar & 80 & Complete \\
\hline 14. & Indah Prima S. & 60 & Not Complete \\
\hline 15. & Inka Fradilla & 90 & Complete \\
\hline 16. & Jerri Mandela simamora & 60 & Not Complete \\
\hline 17. & Klarisa Indah Pasaribu & 80 & Complete \\
\hline 18. & Malik Adwi & 60 & Not Complete \\
\hline 19. & Nesya Kharisma & 90 & Complete \\
\hline 20. & Novita Sari nasution & 80 & Complete \\
\hline 21. & Ningot Rumapea & 90 & Complete \\
\hline 22. & Natanael S & 80 & Complete \\
\hline 23. & Randa Khrisna & 80 & Complete \\
\hline 24. & Irvan Oscar & 60 & Not Complete \\
\hline 25. & Riska Gusti & 80 & Complete \\
\hline 26. & Septi Nanda & 90 & Complete \\
\hline 27. & Sephia Ester & 90 & Complete \\
\hline 28. & Swatutri Pratama & 80 & Complete \\
\hline 29. & Marito bastian $\mathrm{P}$ & 90 & Complete \\
\hline 30. & Tri Mario Yolanda B & 90 & Complete \\
\hline & Total & 2370 & \\
\hline & Average & 79,5 & Complete \\
\hline
\end{tabular}

From the table above, it can be seen that the students' ability in learning the melodies of the main song melodies has reached the minimum completeness criteria. The average value obtained by students is 79.5 out of 30 students. From the level of mastery learning has increased by 24 students, while students who are not complete there are 6 students. Then the cycle or posttest is not continued anymore. 


\section{- Observation of Cycle II}

In the observation stage the observer is the team of lecturers. The results of observations made during the second cycle of learning succeed because the team of lecturers and students in the learning process has made a very optimal effort. The lecturer team in the class has implemented a systematic learning sequence, and students have also understood and applied STAD type cooperative learning methods. So that learning runs smoothly and according to plan. After the test results are checked, the minimum completeness criteria (KKM) has been reached.

\section{- Reflection and Evaluation of the Implementation of Actions II}

From the observations it can be seen that during the learning process the lecturer team has optimized the learning model in the classroom and has implemented learning steps in accordance with the lesson plan. So that the object of learning is not the lecturer team but students.

Test results and observations given in the second cycle are used as a basis for drawing conclusions whether the research is said to be successful or not. If this research meets the established indicators of success then there is no need to proceed to the next cycle.

The following illustrates the increase in student retention starting from the Pre Test, Post Test I to Post Test II

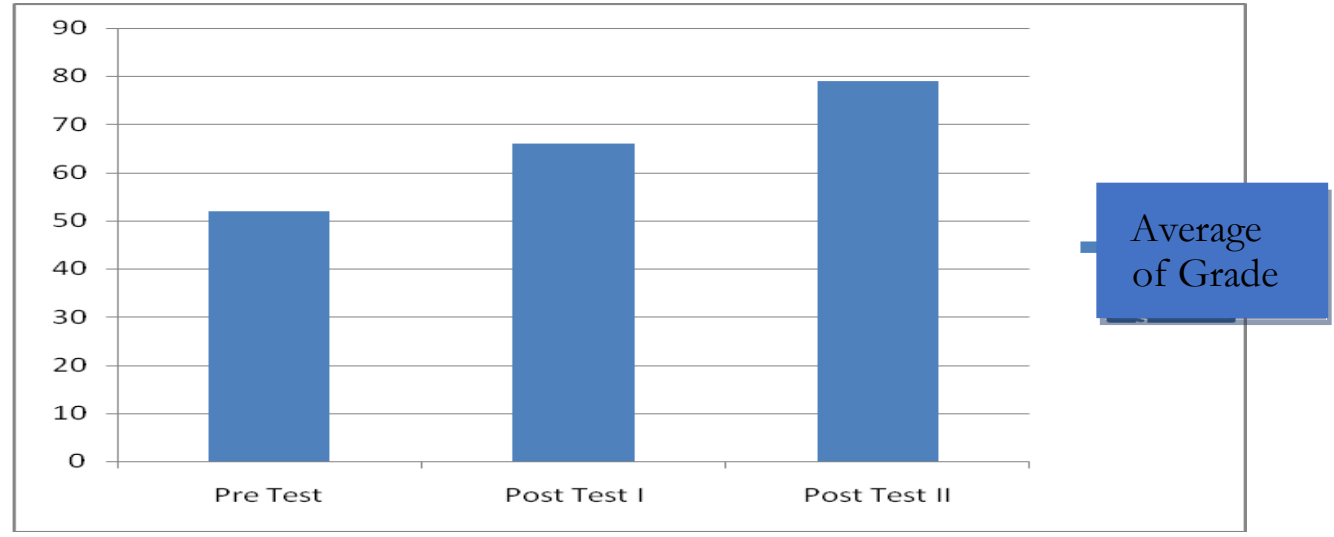

Figure 1. Graph of Average Results for Improving Student Retention

\section{Conclusion}

Based on the results of the discussion that has been done, the conclusions from this study can be drawn, namely:

a. Before implementing the STAD cooperative learning method, data was found through trials with pre-tests, that the average student learning ability in learning was still very low, amounting to 52.3 .

b. In the first cycle by applying the STAD type of cooperative learning methods, and the average student learning outcomes increased by an average of 66.33 but not yet declared complete.

c. In the implementation of the second cycle by applying the STAD type of cooperative learning methods, the average student learning outcomes increased by 79.5 then declared complete and the cycle did not continue.

d. So thus the application of cooperative learning with the STAD model in vocal classes of music education study program semester 2 students in studying the analysis of the basic melodic form of songs can increase learning outcomes very significantly. The increase can be illustrated in the table of increasing resistance to student learning outcomes as follows. 


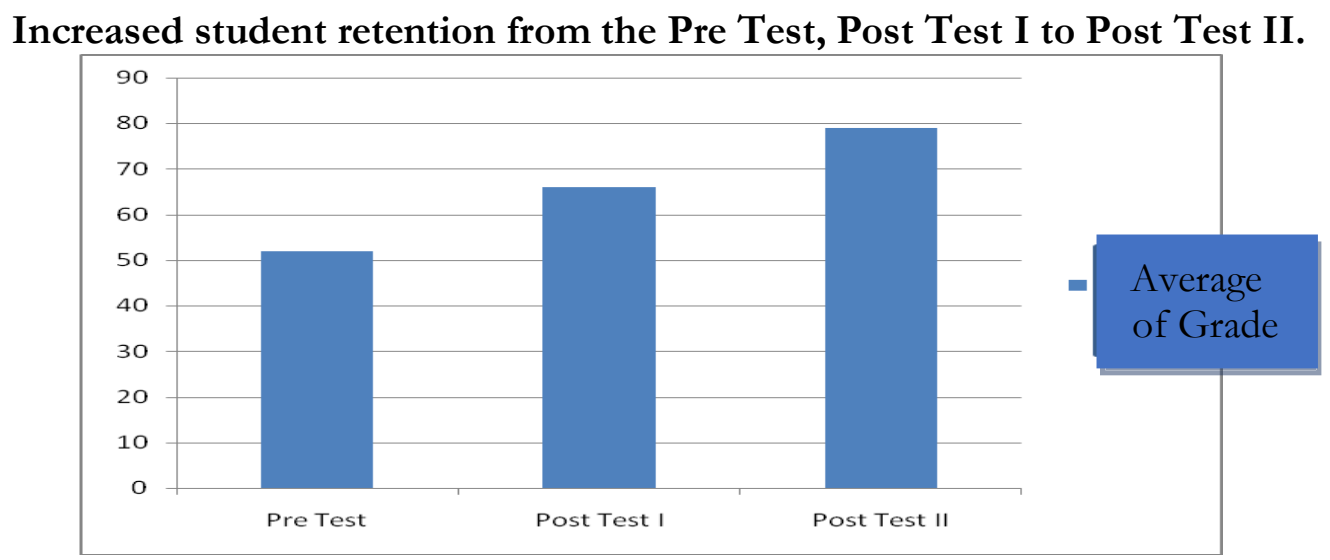

\section{References}

Arends, Richardi, (1997), Classroom Instructional Management, New York: the McGraw-Hill Company.

Djamarah, B, (2006) peningkatan retensi mahasiswa mulai dari tahap Pre Test, Post Test I sampai Post Test II. Strategi Belajar Mengajar, Rineka Cipta, Jakarta

Dick \& Carey. (2001). The Systematic Design Of Instruction. New York: Wesley Educational Ganap, Victor (1993). Kajian Musik Dijenjang Pendidikan Tersier, Jakarta : Jurnal Seni

Jhonson, D.W. and Jhonson, R.T (1986) Learning Together and Alone (2 $2^{\text {nd }}-$ ed). Englewood Cliffs, NJ: Prentice-Hill

Kunandar, (2008), Langkah Mudah Penelitian Tindakan Kelas Sebagai Pengembangan Profesi Guru, Jakarta, rajawali press

K. Chap-as, Patricio. (2019). The Role of Music in Predicting Academic Achievement: A Technological Discovery. Britain International of Linguistics, Arts and Education (Biolae) Journal.

Poerwodarmanto, W.J.S,2002 Kamus Besar Bahasa Indonesia. Jakarta: Balai Pustaka

Rurnama, Adinda. Yus, Adinda. Yus, Anita and Wau, Yasaratodo. (2019). The Profile of Fine Motor Development Achievement in Childrn of Island (5-6 Years Old) in Teulaga Tujuh Langsa Village. Budapest International Research and Critics in Linguistics and Education (BirLE) Journal

Sanjaya, (2006), Metode Pembelajaran, Jakarta Rineka Cipta

Slavin, Robert, (2005), cooperative learning, teori risert dan praktik, Bandung

Sharan, S. and Sharan, Y (1976). Small Group Teaching. Englewood Cliffs, NJ: Educational Technologi Publications.

Sitepu, T. (2019). Cooperative Model in Language Reasoning: Indonesian Language Teaching Materials in Teacher Training and Education Faculty of Muhammadiyah Sumatera Utara University. Britain International of Linguistics, Arts and Education (Biolae) Journal.

Sugiyono, (2009), Metode Penelitian Pendidikan, Alfabeta, Bandung

Surakhmad, (1982), Kurikulun Dan Pembelajaran. Jakarta: Bumi Aksara

Umamik, Siti, (2007), Keefektifan Model Pembelajaran Matematika Kooperati Learning Tipe Stad Melalui Pemanfaatan Alat Peraga Pada Sub Materi Pokok Keliling Dan Luas Daerah Lingkaran Terhadap Hasil Belajar Peserta Didik Kelas VIIi SMP Negeri 4 Kudus T.P 2006/2007, Skripsi, FMIPA, UNNES, Semarang

Wiriaatmadja, Rochiati, Metode Penelitian Tindakan Kelas, Remaja Rosdakarya, Bandung Yatim, Riyanto, (2008), Paradigma Baru Pembelajaran, Kencana Prenada Media Group, Jakarta. 